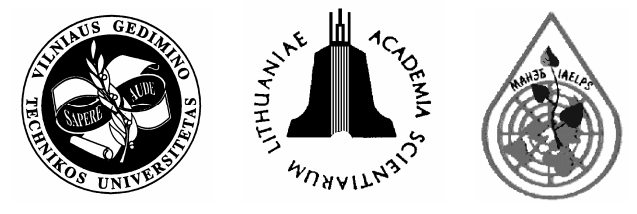

\title{
DESIGN AND REALIZATION OF MONITORING SYSTEM FOR MEASURING AIR TEMPERATURE AND HUMIDITY, WIND DIRECTION AND SPEED
}

\author{
Ján Čimo, Bernard Šiška \\ Dept of Biometeorology and Hydrology, Slovak University of Agriculture in Nitra. \\ E-mail: Jan.Cimo@uniag.sk; Bernard.Siska@uniag.sk
}

Submitted 30 Mar 2006; accepted 18 May 2006

\begin{abstract}
An air humidity sensor based on the capacity principle and programmable digital air temperature sensors are designed in the work. The wind direction and wind speed sensor (anemometer) is based on the optoelectronic principle. Sensors register frequency impulses from the wind fan of the anemometer. Methods and materials conformable with modern electronics and informatics were used. The method of linear regression was used for calibration of sensors. The accuracy of an air temperature sensor was found better than $0,1^{\circ} \mathrm{C}$ in the range from -55 to $125^{\circ} \mathrm{C}$, and an air humidity sensor was better than $1 \%$ in the range from 0 to $98 \%$. The anemometer works in the range of wind velocity from 0 to $150 \mathrm{~km} \cdot \mathrm{h}^{-1}$ with accuracy better than $1 \%$ to $90 \mathrm{~km} \cdot \mathrm{h}^{-1}$ and over $90 \mathrm{~km} / \mathrm{h}$ better than $3 \%$. First of all these sensors were proposed for automatic weather stations widely used in the sector of agriculture (microclimatic weather stations), industry and for other technological operations where monitoring of temperature, wind speed, wind direction and humidity is required. The sensors will be used as models for educational purposes at the lessons of biometeorology and climatology too.

Keywords: air humidity sensor, air temperature sensor, weather stations, anemometer, wind direction sensor, optoelectronic principle.
\end{abstract}

\section{Introduction}

The weather information is an inseparable part of everyday life. Air temperature, speed and direction of wind and air humidity belong to the most important meteorological elements defining ambient atmosphere [1].

The temperature is frequently measured physical element not only in meteorology. The most often principles used in design of temperature sensors are based on measurement of temperature resistance of metal or semiconductor materials, eventually Seeback effect. The following technologies are the most frequent today:

- resistance sensors (RTD),

- thermocouples (TC),

- integrated sensors of temperature (IST).

Integrated temperature sensors (IST) are very often used in modern digital weather stations. IST sensors can offer direct digital answer on measured temperature. Digital output doesn't need linearization and calibration. IST sensor has integrated A/D (analog/digital) convector. The sensors are calibrated during made of production.

The next frequently monitored physical element in meteorology is air humidity. Two measuring methods of air humidity are usually widely used in digital weather station today:

- psychrometric method,

- capacity method.

Psychrometer method is the basic method of air humidity measuring in meteorology. Digital psychrometer consists of two temperature sensors (PT100, IST ...). Vapor pressure and relative humidity are calculated according to psychrometric difference between dry and wet-bulb thermometers [2-4].

Capacity method is based on change of permittivity due to air humidity changes. Humidity sensor is based on the capacity principle and measures frequency impulses from the designed oscillator [5-7].

The measuring of wind direction and wind speed which in meteorological practice today are based on electrical, inductive, mechanical and electronic principle. The paper deals with the design and realization of the wind direction and wind speed sensor (anemometer), which works by the optoelectronic principle and measure frequency impulses from the wind fan of the anemometer [8-11].

\section{Research object and methodology}

\subsection{Description of air temperature measuring}

In this work digital thermometer Dallas DS1620 was used. The DS1620 measures temperature using a bandgap-based temperature sensor. The temperature reading is provided in a 9-bit, two's complement reading by issuing a READ TEMPERATURE command. The data are transmitted serially through the 3-wire serial interface, LSB first [12-16]. 


\subsection{Description of air humidity measuring}

In this work Philips humidity sensor was used which works as a capacitive sensor. Its relative permittivity of material depends on relative air humidity. The main part of an air humidity sensor is a capacitive sensor which consists of a plastic perforate case. In this case there are special foils which are gold-plated with steamed-up thin film. The foil constitutes dielectric of flat capacitor and thin gold coats there are electrodes.

\subsection{Description of optoelectronic principle of anemometer}

The designed anemometer works on the optoelectronic principle with used beam of light transistor, photodiode and shield on shaft. Impulses are sent for other data processing to the PC. The basic role of decoding software is to load arose impulses (" 0 " and " 1 ") on time unit and to add correct value to measurement according to calibration with other measuring accuracy equipment. The sensor which works by optoelectronic principle is better as compared with electromagnetic sensors. Optoelectronic sensors are of smaller geometric dimensions, fault liability and they are safer and more compact [17$21]$.

\subsection{Description of optoelectronic principle of wind direction sensor}

The designed wind direction sensor works on the optoelectronic principle with used three beams of light transistors, three photodiodes and shield on shaft. As compared with the principle mentioned above the impulses of anemometer are also sent to the other data processing to the PC. The role of decoding software is also to load arose impulses ("0" and " 1 ") on time unit and to give correct value to measurement according to calibration with other measuring accuracy equipment. To achieve good accuracy it is very important to make precise mechanical construction of the sensor.

\section{Results and discussion}

\subsection{Design of control unit for air temperature measuring}

The DS1620 can measure temperature over the range of $-55^{\circ} \mathrm{C}$ to $+125^{\circ} \mathrm{C}$ in $0,25^{\circ} \mathrm{C}$ increments. The sensor accuracy is better than $0,1^{\circ} \mathrm{C}$ after calibration.

The calibration is one of the most important parts of this work. The calibration ranged from -25 to $35^{\circ} \mathrm{C}$ and was made by using weather-station mercury thermometer with a final accuracy $0,1^{\circ} \mathrm{C}$. The measuring accuracy from -55 to $-25^{\circ} \mathrm{C}$ and from 35 to $125^{\circ} \mathrm{C}$ is maximum $0,25^{\circ} \mathrm{C}$. The result of the calibration was calibration curve which was integrated to the control program. You can see the designed electrical scheme and calibration curve in Figs 1 and 2.

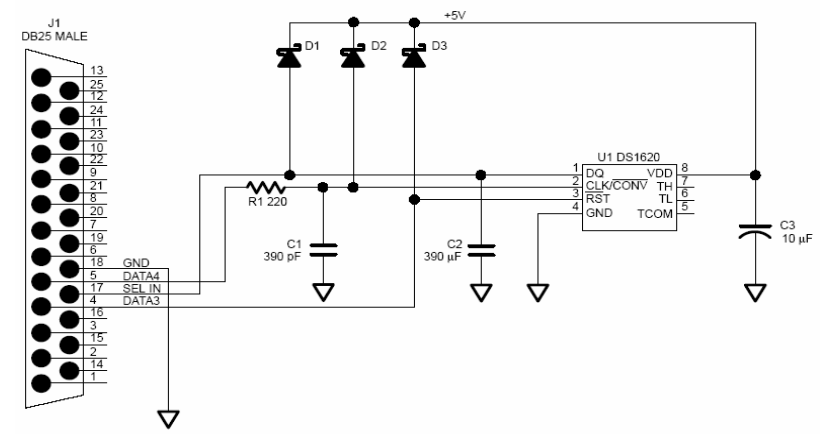

Fig 1. Electrical scheme of measuring accuracy unit with digital thermometer DS 1620

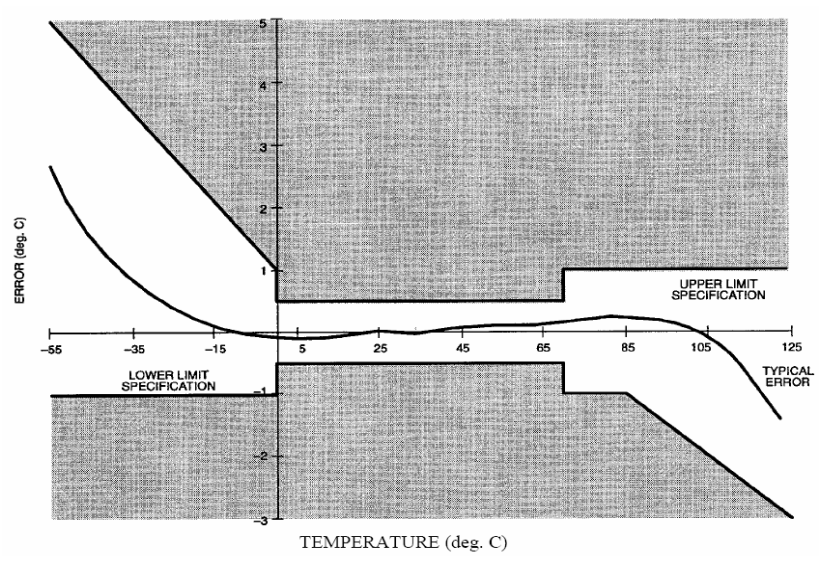

Fig 2. Calibration curve of air temperature measuring accuracy unit

\subsection{Design of control unit for air relative humidity measuring}

The effect of air humidity changes foils permittivity and capacity of a capacitor too (Fig 3). The change of capacity in a humidity sensor must be transformed on relevant electrical signal by A/D (analog-digital) convector (Fig 4).

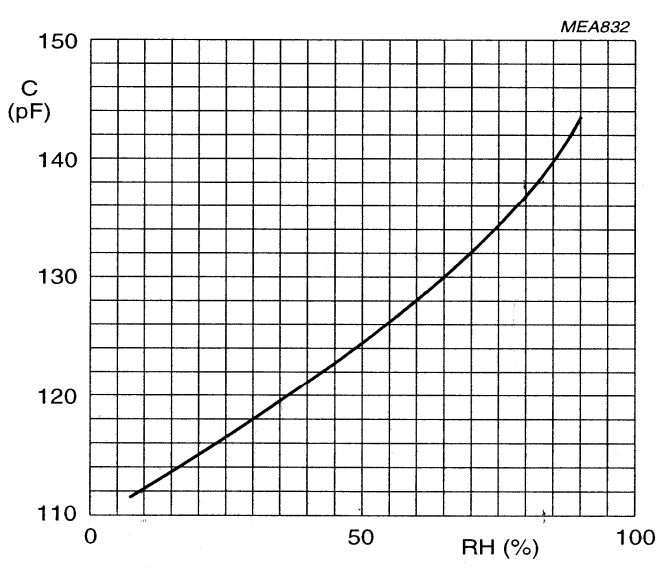

Fig 3. Typical capacitance as a function of relative humidity 


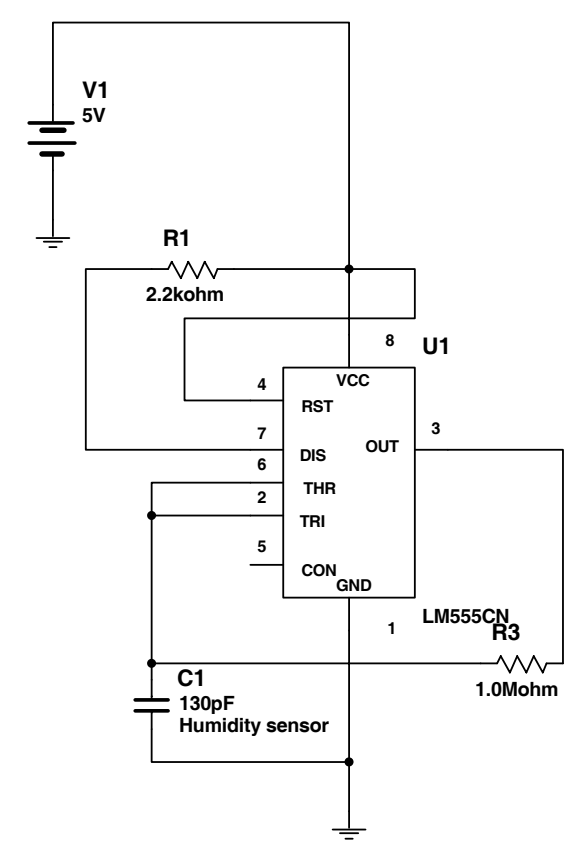

Fig 4. Electrical scheme of air humidity measuring accuracy unit

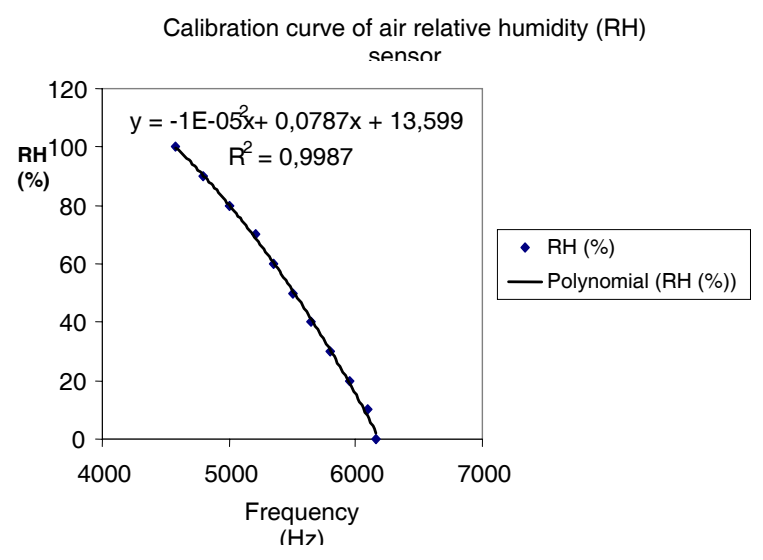

Fig 5. Calibration curve of air humidity measuring accuracy unit

The calibration air humidity unit was realized according to another air humidity sensor which works with an accuracy better than 1\% [22-25]. The calibration (Fig 5) was made by using Miltisim 2001 and Electronics Wokrbench software and then was compared with a professional meteorological instrument. The result of the calibration was a calibration curve, which was integrated to the control program [26].

\subsection{Design of read unit for wind direction and speed measuring}

The principle of this measuring looks very simply. The frequency is measured from anemometer shaft.

An optoelectronic sensor was projected and designed for data evaluation of wind speed on the principle of using beams of light transistors, LED (Light Emitted Diode) photodiodes, and shield on the shaft. According to the shapes of output impulses, sometimes it is needed to add a shaping comparator, because the impulses must be correct. We can see a scheme of coding wheel for wind speed measuring on Table 1. For data evaluation of wind direction, an optoelectronic sensor was projected and designed, which uses eight directions angular resolution. This eight directions angular resolution is suitable for agricultural observation. Producing a sensor with sixteen angular resolutions would be more difficult and complicated. The program evaluates the wind direction according to the following protocol:

North $=0$ degree

Table 1. Eight directions angular resolution of wind direction

\begin{tabular}{|lcccccccc|}
\hline Direct. & $\mathrm{N}$ & $\mathrm{NE}$ & $\mathrm{E}$ & $\mathrm{SE}$ & $\mathrm{S}$ & $\mathrm{SW}$ & $\mathrm{W}$ & $\mathrm{NW}$ \\
\hline$\left(^{\circ}\right)$ & 0 & 45 & 90 & 135 & 180 & 225 & 270 & 315 \\
\hline Bit A & 0 & 0 & 0 & 0 & 1 & 1 & 1 & 1 \\
Bit B & 0 & 0 & 1 & 1 & 1 & 1 & 0 & 0 \\
Bit C & 0 & 1 & 1 & 0 & 0 & 1 & 1 & 0 \\
\hline
\end{tabular}

$\begin{array}{llc}\text { Shortcut } & \text { Wind direction } & \text { Wind azimuth } \\ \text { N } & \text { North } & 360^{\circ} \\ \text { NE } & \text { North - East } & 45^{\circ} \\ \text { E } & \text { East } & 90^{\circ} \\ \text { SE } & \text { South - East } & 135^{\circ} \\ \text { S } & \text { South } & 180^{\circ} \\ \text { SW } & \text { South - West } & 225^{\circ} \\ \text { W } & \text { West } & 270^{\circ} \\ \text { NW } & \text { North - West } & 315^{\circ}\end{array}$

It is much better to use the optoelectronic principle in this coding for identification wind direction. The shield will have the shape of a circle with cut holes to cover and transmit the light on the phototransistors according to the protocol in Table 1 . The mechanical and electronic construction of a sensor will depend on the possibilities of every designer (see Figs 6 and 7). The cut holes are marked by heavy lines.

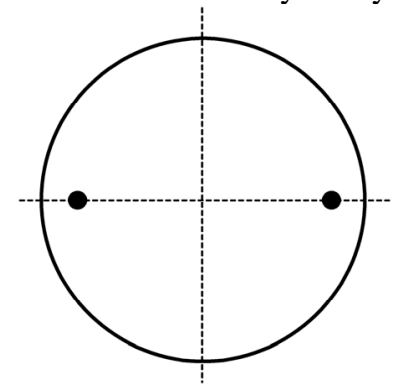

Fig 6. Wind speed shield

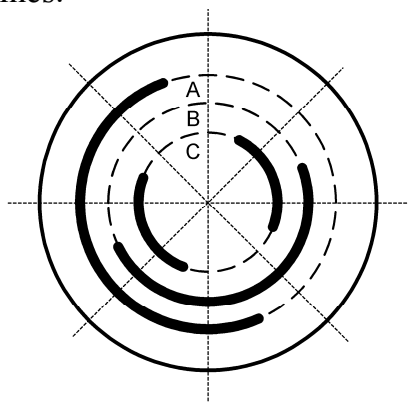

Fig 7. Wind direction shield
The electronic scheme (Fig 8) is placed in a sensor which measures the wind speed and direction. As it was mentioned before, this sensor uses the optoelectronic principle. Infra-red LED is used as power of light.

Infrared LED illuminates the phototransistors through the shield which is sensitive on infra-red light. Phototransistors with a diameter of $\Phi 3 \mathrm{~mm}$ were designed and used because of little space inside the sensor. An output signal is received from the collector resistance and formed by an inventor with Schmitt flip-flop circuit [27]. The parameters of printed circuit boards are adapted to the sensor construction. 


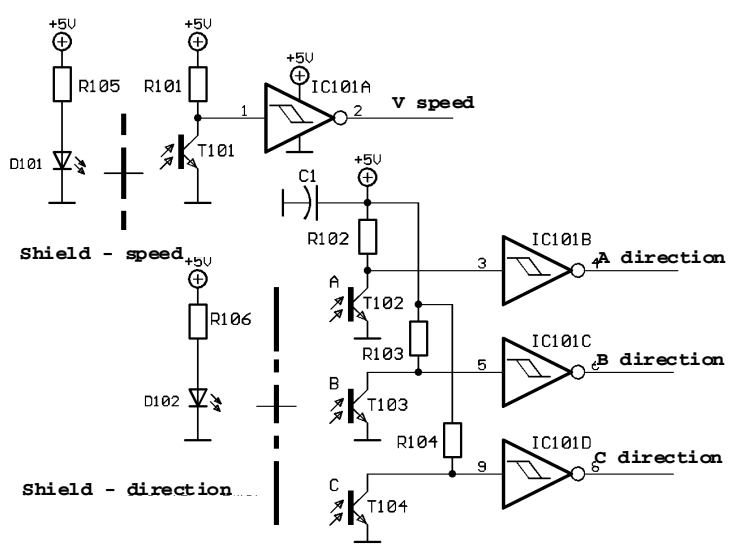

Fig 8. Electrical scheme of wind speed and direction sensor

\section{Calibration of wind speed sensor}

The calibration of a wind speed sensor is very complicated but needed. The impulse quantity depends on the mechanical construction. For calibration we need to know the impulse quantity per period of measurement. During calibration the wind speed sensor was placed on the car roof, and at the same time we monitored the impulse quantity by a digital multimeter Metex $\mathrm{M}-3850 \mathrm{D}$ according to the car speed determined in advance (Table 2). A very important condition is to make calibration when it is calm. The error of measurement will depend on the tachometer and digital multimeter accuracy by which the impulse frequency is measured [28-30]. Škoda Octavia car was used for calibration of equipment. Accuracy of the car tachometer is better than $1 \%$ for a velocity of up to $90 \mathrm{~km} / \mathrm{h}^{-1}$ and $3 \%$ for $90 \mathrm{~km} / \mathrm{h}^{-1}$ and more. The calibration curve was created from measured data by means of mathematic - statistic analysis (Fig 9). The calibration curve was used in the Meteostation software which was written in a programm language $\mathrm{C}++$ Builder [31].

Table 2. Determinated car speeds for calibration of wind speed sensor

\begin{tabular}{|l|l|l|l|l|l|l|l|l|l|l|l|l|l|l|l|l|l|l|}
\hline $\begin{array}{l}\text { Speed } \\
\text { (kmh) }\end{array}$ & 0 & 5 & 10 & 15 & 20 & 30 & 40 & 50 & 60 & 70 & 80 & 90 & 100 & 110 & 120 & 130 & 140 & 150 \\
\hline $\begin{array}{l}\text { Frequency } \\
\text { (Hz) }\end{array}$ & 0 & 1 & 2 & 3 & 5 & 7 & 11 & 13 & 16 & 19 & 22 & 24 & 28 & 31 & 36 & 38 & 41 & 43 \\
\hline
\end{tabular}

\section{Calibration of wind speed sensor}

For a correct function, the direction label must be directed to the North, and the coding shield must be correctly set as it is designed in bit protocol (Table 1). The designed software enables recalibrating of the direction without climbing up the post.

\section{Mechanical construction of wind direction and speed sensor}

The mechanical construction of wind direction and speed sensor was designed by software Mechanical Desktop and AutoCAD (Figs 10, 11).
Calibration curve of wind speed sensor

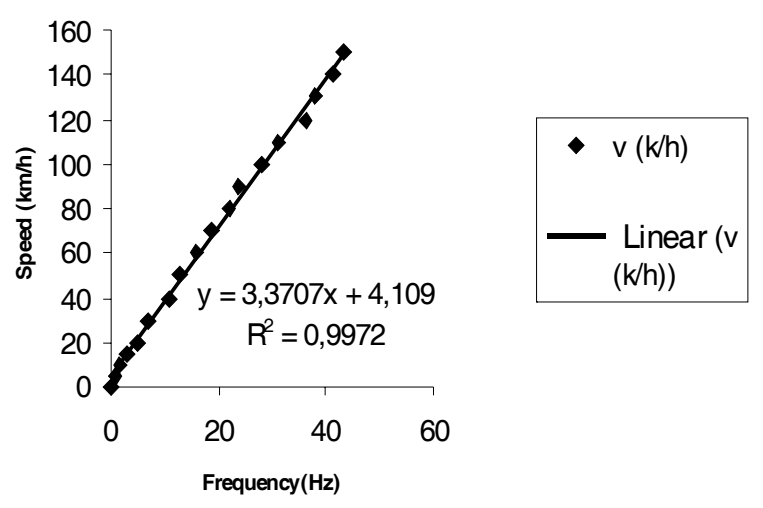

Fig 9. Calibration curve of wind speed sensor

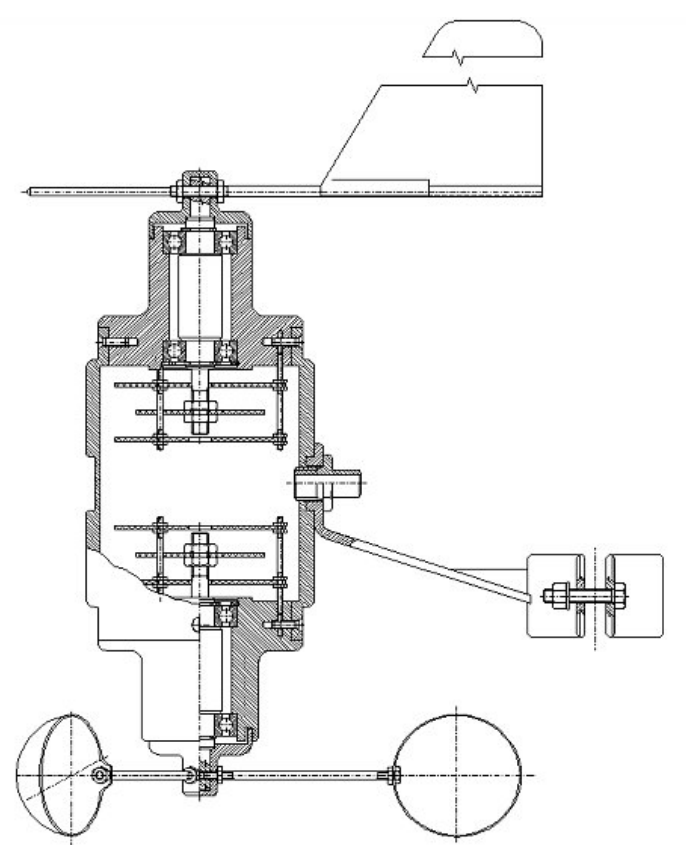

Fig 10. Design of wind direction and speed sensor

\section{Result verification}

After calibration verification of air temperature, air humidity and wind speed sensor (Figs 12-17) was performed.

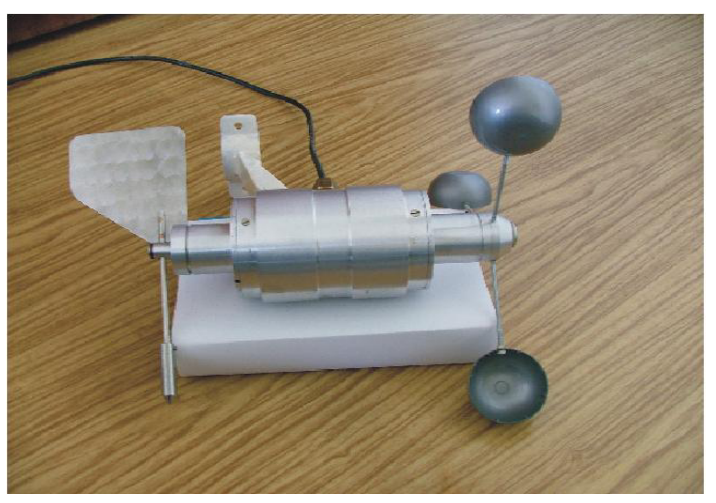

Fig 11. Detail of wind direction and speed sensor 


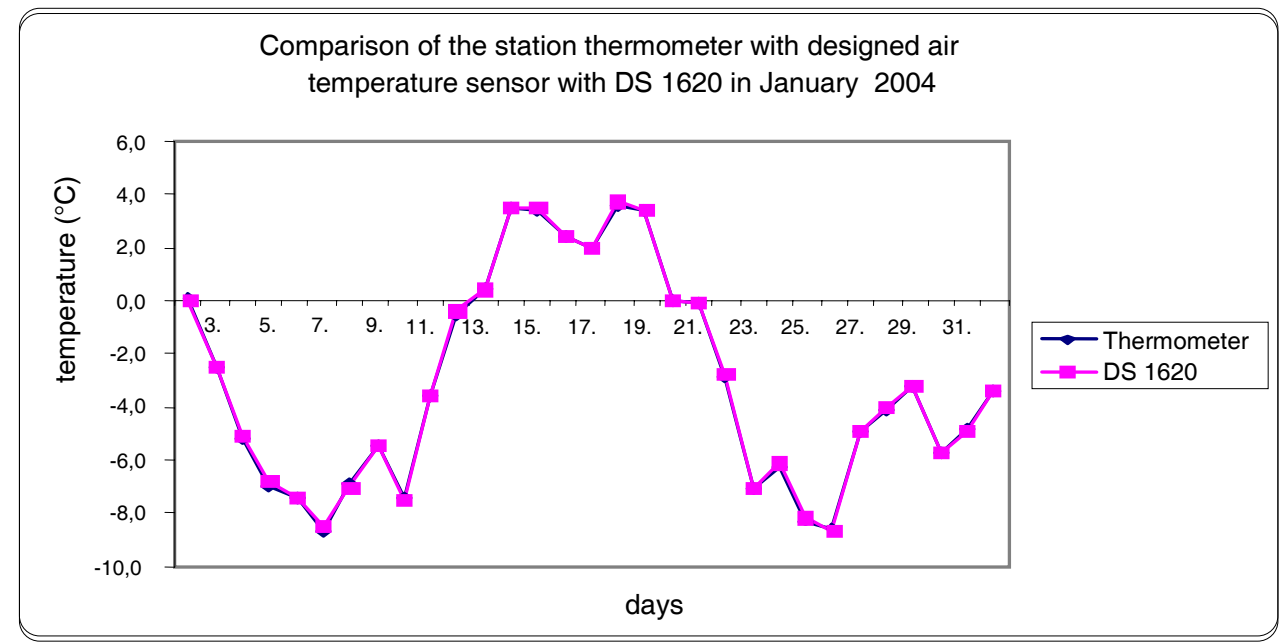

Fig 12. Comparison and verification of designed air temperature sensor in January 2004

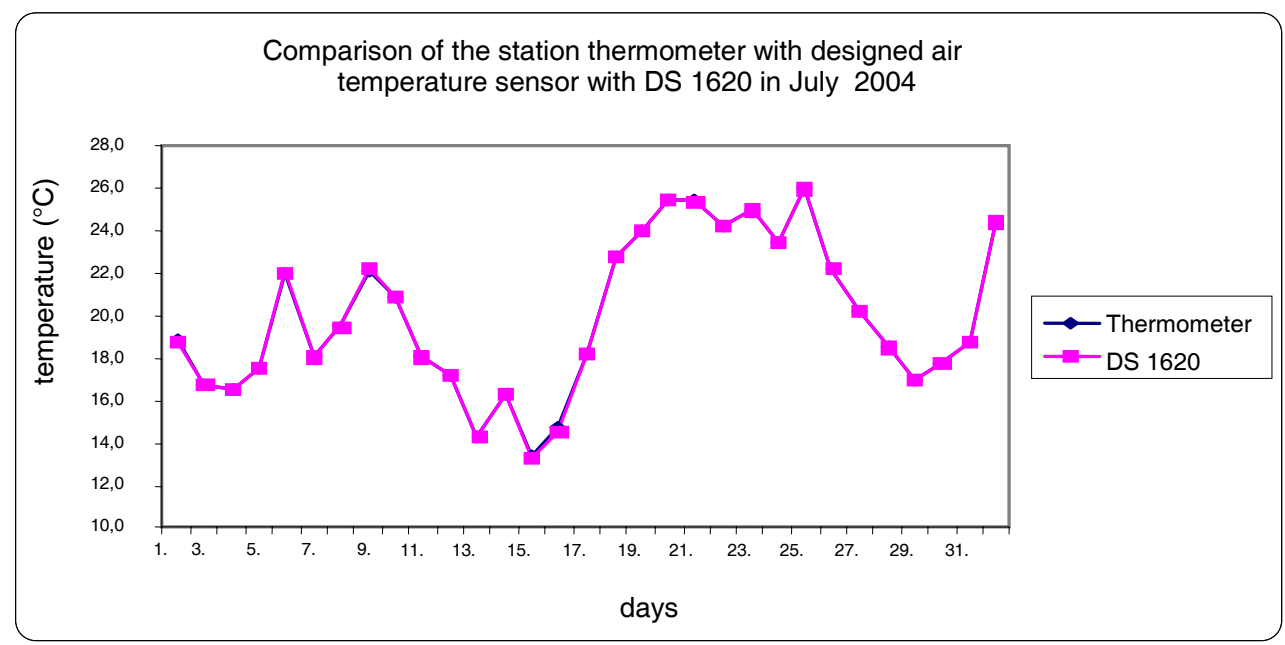

Fig 13. Comparison and verification of designed air temperature sensor in July 2004

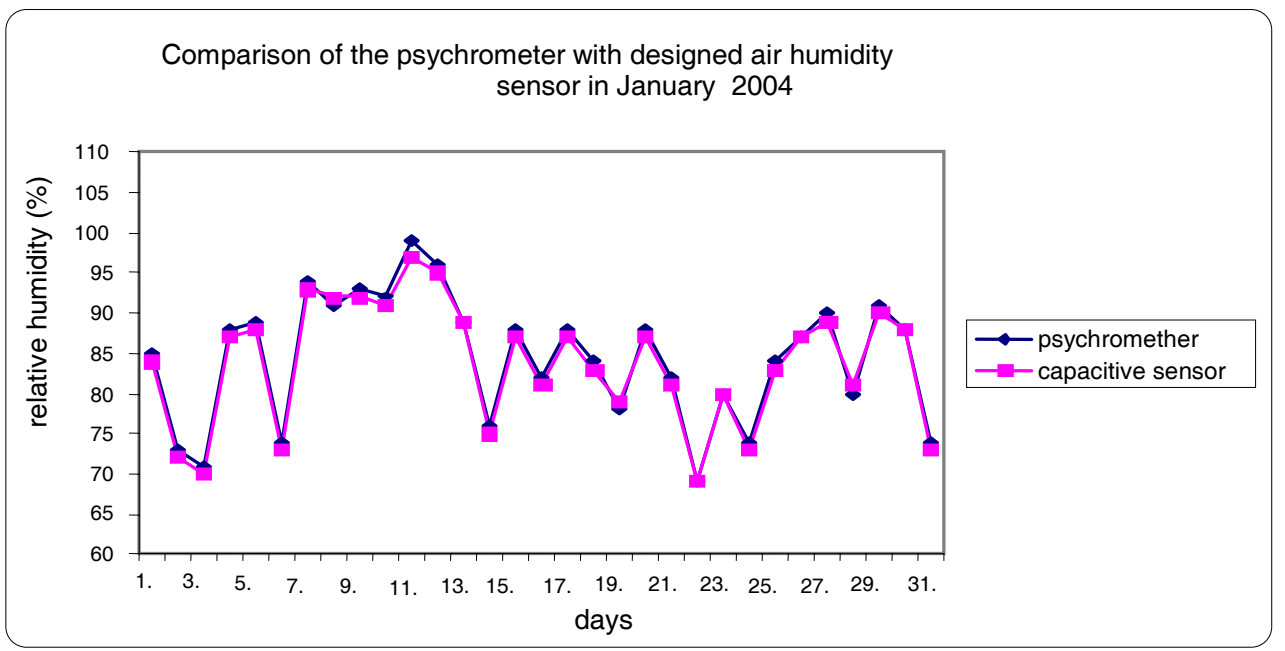

Fig 14. Comparison and verification of designed air humidity sensor in January 2004 


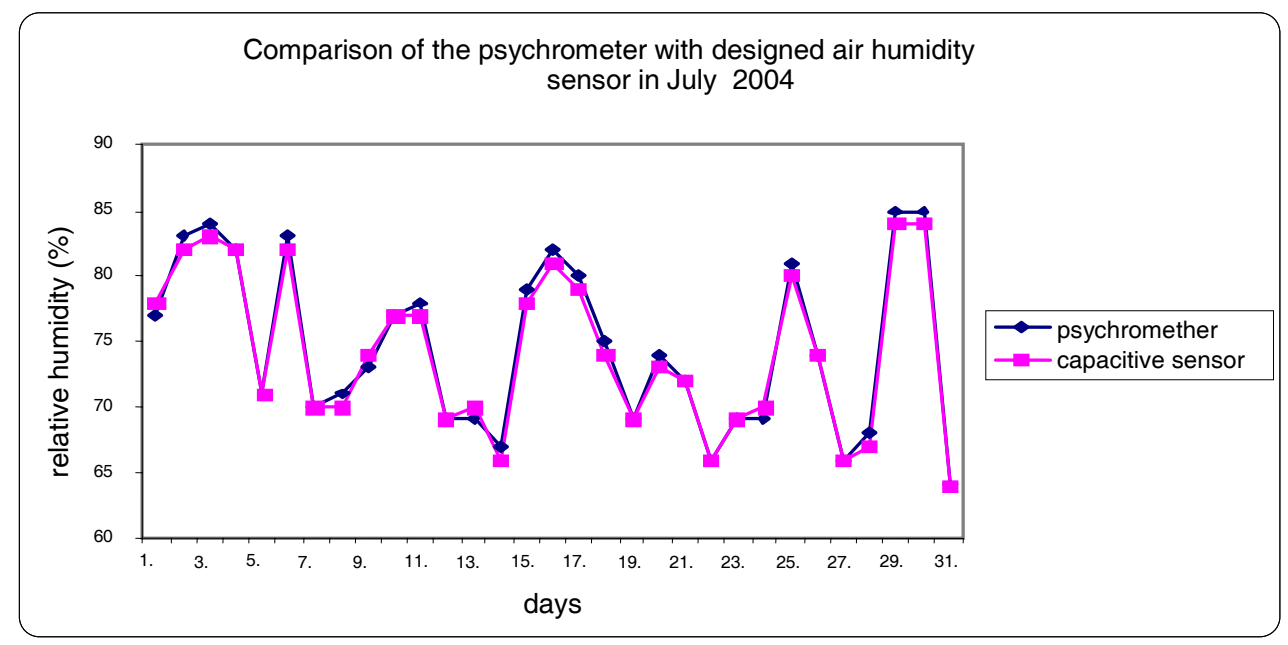

Fig 15. Comparison and verification of designed air humidity sensor in July 2004

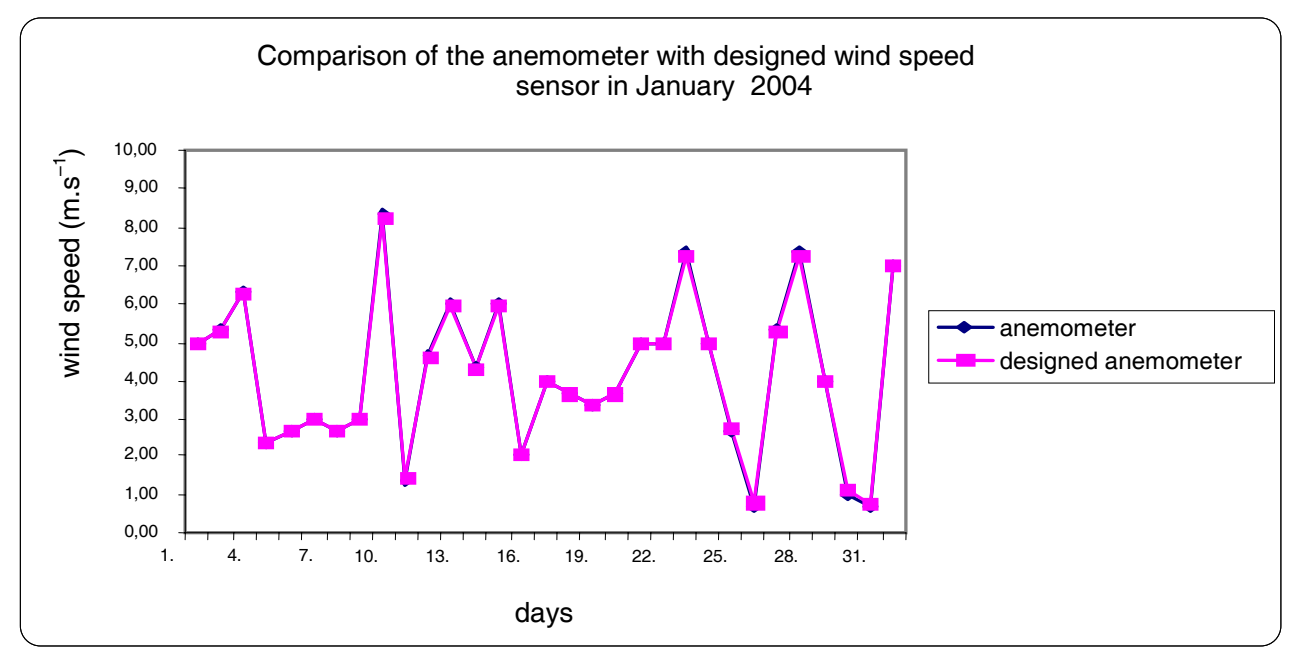

Fig 16. Comparison and verification of designed wind speed sensor in July 2004

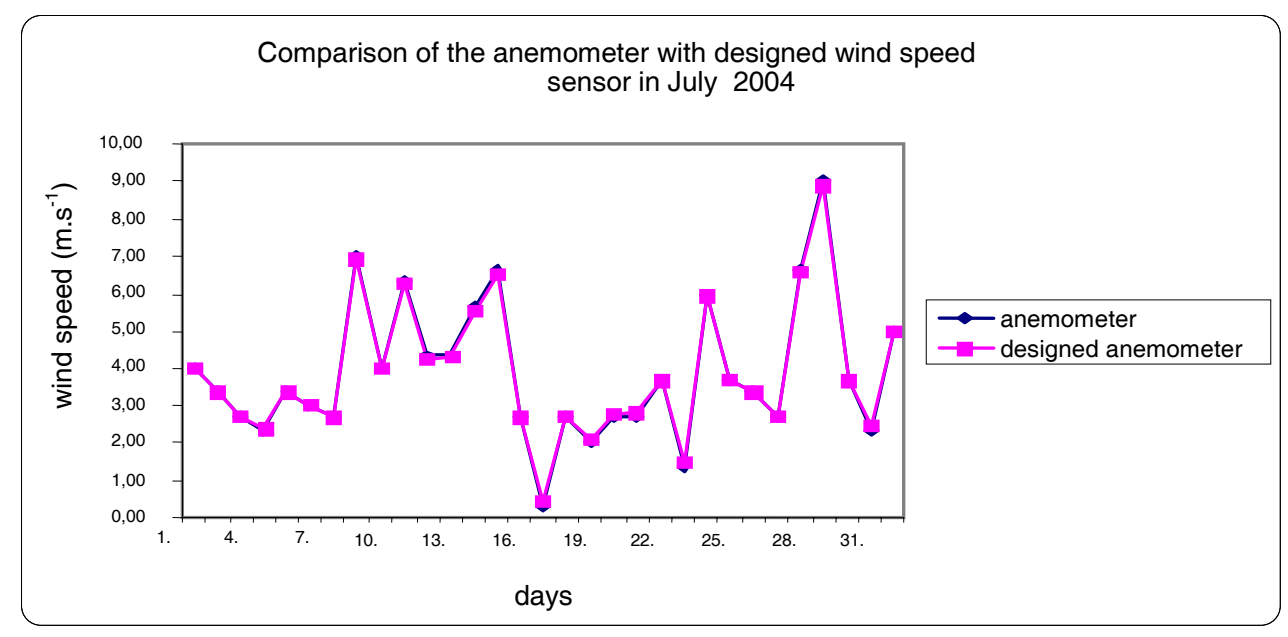

Fig 17. Comparison and verification of designed wind speed sensor in July 2004 


\section{Conclusions}

At the end, we can state that an air temperature sensor works in measuring range from -55 to $125^{\circ} \mathrm{C}$ with an accuracy better than $0,1^{\circ} \mathrm{C}$, and a humidity sensor works in measuring range from 0 to $98 \%$ with an accuracy better than $1 \%$. An anemometer works in the range of wind velocity from 0 to $150 \mathrm{~km} / \mathrm{h}^{-1}$ with an accuracy better than $1 \%$ up to $90 \mathrm{~km} / \mathrm{h}^{-1}$ and over $90 \mathrm{~km} / \mathrm{h}$ better than $3 \%$. If we wanted to reach a better accuracy of the sensors (up to $1 \%$ ), calibration of the anemometer would have to be done in a special calibration tunnel.

The designed air temperature and humidity sensor and the sensor of wind direction and speed can find a wide application in different areas, especially where it is needed to monitor and save data about air temperature and humidity for different agricultural and nonagricultural practices. The main sphere of using air temperature and humidity sensor is at automatic weather stations as well as at agrometeorological and microclimatic stations. There are other uses: firstly as a model that is used for educational purposes at the lessons of the biometeorology and climatology; secondly in the industry and in other technological operations, where it is needed to monitor the air temperature and humidity.

\section{Acknowledgements}

The project was supported by the Grant Agency of the Slovak Republic - VEGA 1/1313/04.

\section{References}

1. Havlíček, V. Agrometeorologie, SZN, 1986. 38 p.

2. Brož, J. Základy fyzikálních měření (I), SPN, 1983. 47 p.

3. Brož, J. Základy fyzikálních měřní (III), SPN, 1983. $110 \mathrm{p}$

4. Fexa, J. Měření vlhkosti, SNTL, 1983. 30 p.

5. Limann, O. Elektronika bez balastu, Alfa, 1990. 118 p.

6. Mádr, V. Fyzikálních měření, SNTL, 1991. 45 p.

7. Krčula, J. Základy automatizácie a robotizácie, VŠP, 1990. $112 \mathrm{p}$.

8. Šiska, B. Praktická biometeorológia, SPU Nitra, 2002. $74 \mathrm{p}$.

9. Repa, Š.; Šiška, B. Climatic charactetics of year 2003 in Nitra. 13, SPU Nitra, 2004. 24 p.

10. Antal, J.; Igaz, D. Aplikovaná agrohydrológia. 3. doplnené a upravené vydanie. SPU, Nitra, 2003. 118 p.

11. Antal, J.; Igaz, D.; Špánik, F. Vplyv meteorologických faktorov na predvegetačnú pôdnu vlhkost' v rôznych pe- stovatel'ských systémoch. In: Mikroklíma porostúmedzinárodný seminár. ČHMU, Brno, 2003. 34 p.

12. Dallas Semiconductor: DS1620 Digital Thermometer and Thermostat, USA. 159 p.

13. Dallas Semiconductor: DS1621 Digital Thermometer and Thermostat, USA. 23 p.

14. Dallas Semiconductor: DS18B20 Programmable Resolution 1-Write ${ }^{\mathrm{TM}}$ Digital Thermometer, USA. $11 \mathrm{p}$.

15. Dallas Semiconductor: DS1820 1-Write ${ }^{\mathrm{TM}}$ Digital Thermometer, USA. 6 p.

16. Application Note 105 High Resolution Measurement With Dallas Direct-to-Digital Temperature Sensors, Dallas Semiconductor. $108 \mathrm{p}$.

17. Kainka, B. Využití rozhraní PC pod Windows - měření, řízení a regulace pomocí standardních portú $\mathrm{PC}, \mathrm{BEN}$, 2000. 37 p.

18. Hájek, J. Časovač 555 praktická zapojení, BEN, 1999. $58 \mathrm{p}$.

19. STMicroelectronics: Low powersingle CMOS trimer, Italy, 1999. $16 \mathrm{p}$.

20. Analog Devices: AD654 Low Cost Monolithic Voltageto-Frequency Converter, USA, $16 \mathrm{p}$.

21. National Semiconductor: LM131A/LM131, LM231A/LM231, LM331A/LM331 Precision Voltage-toFrequency Converter, National Semiconductors Corporation, USA. 1995. 35 p.

22. Motorola Semiconductor Technical data: Integrate Silicon Pressure Sensors Altimeter/Barometer Presure Sensor OnChip Signal Conditioned, Temperature Compensated and Calibrated, Motorola, Inc., USA, 1997. 49 p.

23. Baker, B. Operational amplifier macromodels, BurrBrown Corporation, USA, 1993. 46 p.

24. EXAR ... the analog plus company: XR-4151 Voltage-toFrequency Converter, EXAR Corporation, USA, 1997. $98 \mathrm{p}$.

25. STMicroelectronics: Low noise J-FET quad operation amplifiers, Italy, 2000. 54 p.

26. Prata, S. Mistrovství v C++, Computer Press Praha 2001. $654 \mathrm{p}$.

27. Data Sheet $74 \mathrm{HC} / \mathrm{HCT} 14$ Hex nvertor Schmitt trigger, Philips, 1993. 37 p.

28. Skalický, P. Mikroprocesory řady 8051, Ben, 1998. 24 p.

29. Kočiš, I. Mikroprocesory a mikropočítače, Alfa, 1986. $67 \mathrm{p}$.

30. Rezák, M. Jednočipové mikropočítače, Magnet-Press, 1983. 127 p.

31. Smolka, J. Programovanie jednočipových mikropočítačov série 8051, Bratislava, 1989. 57 p.

\section{ORO TEMPERATŪROS IR DRE்GNIO BEI VĖJO KRYPTIES IR GREIČIO MATAVIMO STEBĖSENOS SISTEMOS KŪRIMAS}

\section{J. Čimo, B. Šiška}

Santrauka

Straipsnyje aprašomi sukurtieji oro drègnio, oro temperatūros bei vėjo krypties ir vejo greičio (anemometras) jutikliai, pagrịsti optiniu-elektroniniu principu. Jutikliai registruoja anemometro menčiu sukeliamus dažnio impulsus. Kuriant ịrengini taikyti nūdienos elektronikos ir informatikos metodai ir medžiagos. Jutikliai kalibruoti remiantis tiesinès regresijos metodu. Nustatytas oro temperatūros jutiklio, matuojant nuo -55 iki $125^{\circ} \mathrm{C}$, tikslumas buvo didesnis nei $0,1^{\circ} \mathrm{C}$, o oro drejgnio jutiklio, matuojant nuo 0 iki $98 \%$, - didesnis nei $1 \%$. Matavimo anemometru ribos yra nuo $0 \mathrm{iki} 150 \mathrm{~km} / \mathrm{h}$, tikslumas - didesnis nei $1 \%$, kai vejjas siekia iki $90 \mathrm{~km} / \mathrm{h}$ greičio, bei didesnis nei $3 \%$, kai vejjo greitis viršija 90 km/h. 
Jutiklius rekomenduota naudoti automatinėse mikroklimatinių sąlygų matavimo stotyse, plačiai taikomose žemės ūkyje, pramonejje bei kitiems tikslams, kai būtini temperatūros, vejo greičio, vejjo krypties bei drègnio matavimai. Jutikliai bus naudojami ir švietimo tikslams, dėstant biometeorologiją bei klimatologiją.

Prasminiai žodžiai: oro drègnio jutiklis, oro temperatūros jutiklis, mikroklimatinių sąlygų nustatymo stotys, vejjo krypties jutiklis, optinis-elektroninis principas.

\section{ПРОЕКТИРОВАНИЕ И РЕАЛИЗАЦИЯ СИСТЕМЫ МОНИТОРИНГА ДЛЯ ИЗМЕРЕНИЯ ТЕМПЕРАТУРЫ ВОЗДУХА, АТМОСФЕРНОЙ ВЛАЖНОСТИ, НАПРАВЛЕНИЯ И СКОРОСТИ ВЕТРА}

\section{Я. Чимо, Б. Шишка}

Резюме

Описаны сенсоры атмосферной влажности, температуры воздуха, а также скорости и направления ветра (анемометр), который работает по опто-электронному принципу. Сенсоры фиксируют частные импульсы, создаваемые лопатками анемометра. Для создания аппарата были применены новейшие методы и материалы современной электроники и информатики. Для калибрации сенсоров был использован метод линейной регрессии. Установленная точность сенсора температуры воздуха была больше, чем $0,1^{\circ} \mathrm{C}$, в пределах от 55 до $125^{\circ} \mathrm{C}$, а точность сенсора атмосферной влажности была больше, чем $1 \%$, в пределах от 0 до $98 \%$. Пределы измерения анемометра составили от 0 до 150 км/ч, точность - больше, чем $1 \%$, когда скорость не превышала 90 км/ч, и больше, чем $3 \%$, когда скорость превышала 90 км/ч. Созданные сенсоры рекомендуется использовать в качестве оборудования станций для измерения микроклиматических условий. Такие станции широко используются в сельском хозяйстве, промышленности и для других целей, требующих измерения температуры или влажности воздуха, скорости и направления ветра. Сенсоры будут также использоваться при изучении студентами курсов по биометеорологии и климатологии.

Ключевые слова: сенсор атмосферной влажности, сенсор температуры воздуха, станции для измерения микроклиматических условий, сенсор направления ветра, опто-электронный принцип.

Ján ČIMO. PhD, assistant of Dept of Biometeorology and Hydrology, Slovak Agricultural University in Nitra (SAU), Slovak Republic.

PhD, SAU, 2005. Publications: author (with co-authors) of 20 scientific publications. Research interests: biometeorology, climatology, projection and design of meteorological sensors.

Bernard ŠIŠKA. PhD, Assoc Prof, Dept of Biometeorology and Hydrology, Slovak Agricultural University in Nitra (SAU), Slovak Republic.

PhD, SAU, 1992. Assoc Prof since 1999. Publications: author or co-author of more than 80 research papers and 8 monographs. Research interests: crop - weather modeling, climate change impacts. Membership: member of Editorial Board of Acta Scientiarum Polonorum, vice chairman of Slovak Bioclimatological Society of Academy of Sciences of Slovak Republic. 